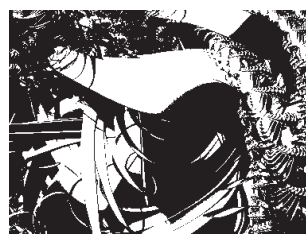

doi:10.5559/di.20.1.07

\title{
SUICIDE IN \\ TAIWAN'S SOCIETY
}

Govindasamy AGORAMOORTHY

College of Humanities and Social Sciences, Tajen University, Pingtung, Taiwan

Minna J. HSU

National Sun Yat-sen University, Kaohsiung, Taiwan

UDK: 316.624(529):179.7

Pregledni rad

$$
314.424 .2(529)
$$

Primljeno: 27. 4. 2009.

Taiwan is a modern industrialized megalopolis clinging to the fringes of the ancient Chinese culture. This tiny island has evolved from agricultural backwater status to global technological giant over the last few decades. Despite the economic prosperity and democratic reforms, social problems involving suicide additionally emerged, and suicide became one of the top ten major causes of death since 1982. In this paper, we have presented data on the occurrence of suicide in Taiwan between 1986 and 2007. We have explored the socio-cultural, religious and economic elements associated with suicide in Taiwan's society. We have also outlined certain measures to minimize the occurrence of suicide in Taiwan in the near future.

Keywords: causes of suicide, methods of suicide, culture, religion, society, Taiwan

Minna J. Hsu, Department of Biological Sciences, National Sun Yat-sen University, No. 70, Lien Hai Road, Kaohsiung 80424, Taiwan.

E-mail: hsumin@mail.nsysu.edu.tw

Suicide is a complex phenomenon associated with psychological, biological and social factors. The word 'suicide' originates from Latin 'suicidium' or kills oneself - the act of terminating one's own life. Suicide may occur for a variety of reasons that include extreme depression, shame, guilt, desperation, pain, pressure, anxiety, financial loss and other undesirable situations. Suicide victims usually follow either the physical mode or chemical mode to end their lives. The physical mode invol- 
DRUŠ. ISTRAŽ. ZAGREB GOD. 20 (2011),

BR. 1 (111)

STR. $137-150$

AGORAMOORTHY, G. HSU, M. J.:

SUICIDE IN TAIWAN'S... ves incapacitating respiratory or central nervous system by destroying key components while the chemical mode interrupts the vital biological processes in the human body. One of the cheapest chemical modes of suicide involves inhaling poisonous gases. ${ }^{1}$

According to the World Health Organization, one person commits suicide every 39 seconds making it one of the leading causes of human death in the world (Bertolotei and Fleischmann, 2002; Krastev, 2006). This uniquely human affair of suicide continues to be a major social problem facing many nations for decades (Farberow, 1975). Therefore, understanding the causes and patterns associated with this bizarre behavior remains a dilemma facing social scientists. The question, however, is: why the often life-caring humans turn towards self-destruction at times? Of course, suicide is not only a tragedy for the family involved, but also a social dilemma for the society. Therefore, understanding the causes, methods and patterns is crucial, so that appropriate strategies can be developed to overcome this thorny social issue facing the society (Lester, 2008).

The small island of Taiwan (area $36,000 \mathrm{~km}^{2}$ ), which is officially called as the 'Republic of China' lies on the Tropic of Cancer. It is separated from the mainland China by a narrow strait, which is only $130 \mathrm{~km}$ wide at its narrowest. ${ }^{2}$ This small island nation has evolved from agricultural backwater status to global technological giant over the past few decades. Taiwan harbors a population of 22.6 million of which 18 million are native Taiwanese immigrated from Fujian and Guangdong Provinces of the mainland China, officially known as the 'Peoples Republic of China' during the 18th and 19th centuries. Besides, 370,000 aborigines inhabit the central and eastern parts of the island and are believed to be of Malayo-Polynesian origin (Agoramoorthy and Hsu, 2007a).

Following the Communist victory of the Chinese Civil War in 1949, two million Kuomintang (KMT) nationalists from the mainland fled to Taiwan and established an authoritarian government claiming sovereignty over China and Greater Mongolia (Agoramoorthy and Hsu, 2007a). Taiwan remained as a totalitarian state throughout the 1970s and 1980s (Gold, 1986). During the 1990s, the ruling KMT nationalists gradually democratized and Taiwan underwent its first peaceful and democratic transfer of power in 2000 from the KMT party to the Democratic Progressive Party (DPP). When the totalitarian regime was in power between 1955 and 1999, Taiwan's average GDP growth was more than $8 \%$. Taiwan experienced economic decline for the first time only in 2001 with a $-2.2 \%$ contraction after democratic reforms started, which furthermore 
DRUŠ. ISTRAŽ. ZAGREB GOD. 20 (2011),

BR. 1 ( 111 )

STR. $137-150$

AGORAMOORTHY, G., HSU, M. J.:

SUICIDE IN TAIWAN'S. coincided with outside factors involving the 2001 September 11 terrorist attacks and the subsequent recession in the USA (Taiwan's largest trade partner). Taiwan's economy was also hampered during the SARS outbreak and the unemployment started to rise steadily since 2000. Experts have blamed the economic downturn in Taiwan on the onset of democracy, arguing that a totalitarian government might not have abided by the values of Western-style democracy, but it certainly delivered economic prosperity to the people. But Taiwan's newly gained democracy brought mostly demands from people to develop their backyards without a long-term vision for the nation (White, 2005).

Although Taiwan's DPP stayed in power from 2000 to 2007 promoting democratic prosperity, human mortality by suicide steadily increased and suicide became one of the top 10 leading causes of death triggering a social crisis (Agoramoorthy and $\mathrm{Hsu}, 2007 \mathrm{~b}$ ). In this paper, we have presented data on the occurrence of suicide in Taiwan between 1986 and 2007. We have discussed the socio-cultural, religious and economic elements associated with suicide in Taiwan's society. We have also suggested certain measures to mitigate future social crisis involving suicide in Taiwan.

\section{SOCIO-CULTURAL AND RELIGIOUS IMPLICATIONS OF SUICIDE}

Suicide has been reported to reflect social values influenced by local culture (Farberow, 1975). ${ }^{3}$ With the exception of the aborigines, most of the people of Taiwan are immigrants from the mainland China, therefore following the Chinese tradition that views suicide as awful, risky and pathetic (Zheng et al., 1986; Xu, 1987). On the contrary, culture in the West perceives suicide as a mental disorder and is therefore treated within the scope of mental health care. According to Tzeng (2001), suicide victims throughout Taiwan face emotional distress in social life involving two basic cultural values, namely, saving face (mientze in Chinese) and filial piety (Hsiao in Chinese).

When people in Taiwan express their suicidal feelings to their family members, it often ends up in harming social relationships, which is similar to how the ethnic Chinese families cope with patients of mental illness and Alzheimer's disease (Hinton et al., 2000; Lee et al., 2001; Lin et al., 1982). Reports also indicate that patients and their families keep suicide secretive in Finland because of shame, and they also avoid talking about it by creating a barrier between family members (Vuokila-Oikkonen et al., 2002). This further shows that patients with suicidal attitudes and their families usually feel stigmatized because they are viewed by the society as different, de- 
DRUŠ. ISTRAŽ. ZAGREB GOD. 20 (2011),

BR. 1 (111)

STR. $137-150$

AGORAMOORTHY, G. HSU, M. J.:

SUICIDE IN TAIWAN'S. fective, and disgraceful, which in turn triggers negative family relationships.

Asia leads the world in the number $(61 \%)$ of suicide cases (Vijayakumar, 2005). In Taiwan, the suicide rate has been alarmingly increased from 6.4 per 100,000 people in 1993 to 17.2 per 100,000 people in 2007 . When the renowned television comedian, Ni Min-Jan took his life in 2005, his suicide was in the media spotlight until another suicide of a couple who met over the internet chat room took its place. Such exaggerated media coverage also promotes suicide as a ritualized phenomenon. For example, in 1998, when a woman in Hong Kong committed suicide by sealing her apartment and burning charcoal until she died of asphyxiation, the news media sensationalized her death. Subsequently, the same technique was adopted in Taiwan as a popular method to commit suicide in confined rooms, cars, and toilets. Besides, several internet sites advertise suicide options with news updates where people with suicidal intent can find company. Taiwan being a developed democratic nation with high literacy rate $(99 \%)$, cheaper and faster internet access is available generally enhancing ample social opportunities for suicide seekers.

Research indicates that the rate of suicide is lower among people who have strong religious faith (Zhang and Jin, 1996; Eskin, 2004). For example, the Islamic religion forbids suicide. ${ }^{4}$ Similarly, the Hebrew faith explicitly prohibits suicide. Nonetheless, Taiwan's major religions such as Buddhism, Taoism and Confucianism are passive and they do not emphasize stringent regulations to forbid suicide. According to Confucianism, the preservation of life is good, but not the supreme good; similarly death is an evil, but not the supreme evil. Nonetheless, the cordial moral values of 'ren' (compassion) and 'yi' (righteousness) are the supreme good, so one should sacrifice life passively or actively to uphold the values. Failure to follow this is considered ethically worse than death. Therefore, suicide is not only morally permissible but also admirable if it's done for the sake of promoting compassion and righteousness (Lo, 1999).

Similarly, Taoism believes that in the end, life negates itself, so death is viewed as a relief, and the victims of suicide may show this relief through death. The ancient Buddhist texts also include cases of suicide, where the Buddha himself accepted it at times. For example, the suicides of Vakkali and Channa were praised by the Buddha because their minds were desireless and they attained enlightenment at death (Koshiro, 1988). .5 Similarly, another disciple named Godhika, who was believed to have slipped in and out of enlightenment and consciousness, and after six times, he committed suicide. While 
cautioning against suicide, the Buddha apparently blessed and praised Godhika's steadiness of mind and purpose, and declared that he attained nirvana (ineffable ultimate) to attain disinterested wisdom and compassion (Koshiro, 1988).

\section{TAIWAN'S SUICIDE DATA COLLECTION AND ANALYSIS}

Data on Taiwan's suicide mortality were pooled from the archives of the Manpower Statistics, covering all villages, towns and cities between 1986 and 2007 (Taiwan National Statistics, 2008). All mean values were presented as \pm 1 standard deviation. The Pearson correlation was used to analyze the relationships among the economic growth (\%), gross domestic product (GDP) per capita (USD), the standardized suicide rates (per 100,000), and unemployment rate (\%) from 1986 to 2007. Sex differences of standardized suicide rates and unemployment rates from 1986 to 2007 were tested by paired student t-tests. The Pearson correlation was used to analyze the relationships among the sex-specific standardized suicide rates (per 100,000) and unemployment rate $(\%)$ of the gender. The analysis of variance (ANOVA) and regression was further used to analyze relationships between sex-specific unemployment rate $(X)$ and the standardized suicide rates per 100,000 for males, or for females $(\mathrm{Y})$. Besides, the regression analysis was used to test the relationships of the age-specific standardized suicide rate $(\mathrm{Y})$ and the age-specific unemployment rate $(X)$ between the age 15 to 64 each with 5 years apart, and 65 and above.

\section{METHODS OF SUICIDE IN TAIWAN}

- Between 1986 and 1990, the most frequent method to commit suicide in Taiwan was by self-poisoning with the use of solid or liquid substances. However, hanging including strangulation and suffocation became Taiwan's leading method of suicide from 1991 to 2007. The relative frequencies of suicide by gas poisoning or gassing also increased rapidly (1.5 to 2.6 times) from 1996 to 2002, and it became Taiwan's second most popular method to commit suicide since 2004 (Figure 1).

Overall, the most common method to commit suicide in Taiwan was by hanging $(43.2 \% \pm 6.6, \mathrm{n}=22)$ followed by poisoning $(33.3 \% \pm 13.1, \mathrm{n}=22)$, gassing $(8.0 \% \pm 11.4, \mathrm{n}=22)$ and leaping from roof tops $(6.3 \pm 3.7, \mathrm{n}=22$; Figure 1$)$. When socially and economically distressed parents initiated family suicide across Taiwan, gassing was preferred as the cheapest way. Usually, the parents bought charcoal pack for USD 1 from the local market. After reaching home, they sealed all doors and windows, burned the charcoal to produce smoke, and the poisonous carbon monoxide gas filled the rooms slowly choking the entire family to death. 
$\rightleftharpoons$ FIGURE 1

Relative frequency of six major suicide options recorded between 1986 and 2007 in Taiwan

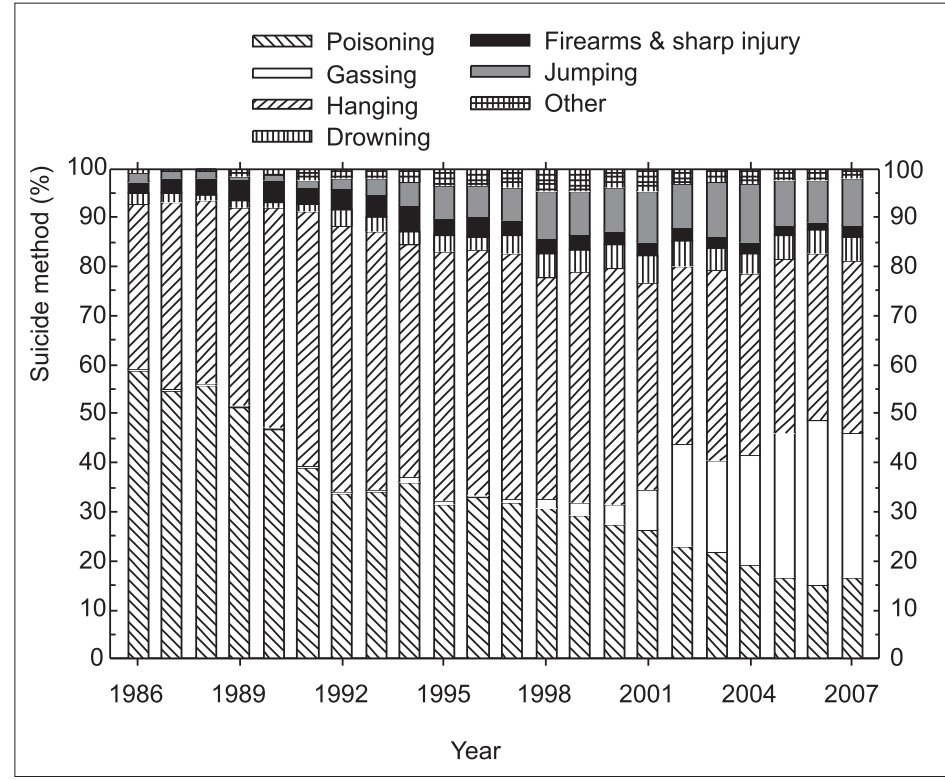

Suicide by gas was more common between 2000 and 2007 when Chen Shui-bian was the President of Taiwan. When the DPP came to power under his leadership in 2000, economic problems emerged by way of closure of small businesses, relocation of local businesses overseas (mostly to mainland China), and the associated job losses. For example, Taiwanese firms invested USD 2.88 billion in the mainland China during the first five months in 2006, which was 46\% higher than in 2005 (Nystedt, 2006). The anti-China stance of Taiwan's government also contributed not only to the increased isolation of Taiwan in regional/international diplomatic activities but also to the loss of local business growth (Sutter, 2006). Besides, serious cases of financial mismanagement and corruption surfaced during the DPP regime, implicating the President and his associates. But the subsequent general election brought back the KMT nationalists, led by Harvard-educated Ma Ying-jeou, to power, given that people in general had hopes that the KMT might revive the social, political and economic atmosphere. The optimism, however, was reflected in the decrease in the suicide rate (2.1 suicides per 100,000 population) and number of cases (from 4,406 to 3,933 deaths) from 2006 to 2007.

\section{CAUSES OF SUICIDE IN TAIWAN}

When Taiwan's population increased from 19.4 million in 1986 to 22.8 million in 2007, the GDP and income per capita also increased fourfold (Figure 2).

Taiwan's average economic growth was $6.29 \% \pm 2.88(\mathrm{n}=22$, range $-2.17 \%-12.66 \%$ ) between 1986 and 2007; the growth 
DRUŠ. ISTRAŽ. ZAGREB GOD. 20 (2011),

BR. 1 (111),

STR. 137-150

AGORAMOORTHY, G., HSU, M. J.:

SUICIDE IN TAIWAN'S...

๑ FIGURE 2

Taiwan's economic growth (\%), GDP and income per capita (USD) and population changes between 1986 and 2007

(1) TABLE 1

Pearson correlation coefficient matrix for the standardized suicide rates (per $100,000)$, economic growth (\%), GDP per capita (USD) and unemployment rate (\%) between 1986 and 2007 in Taiwan

was in negative territory only in 2001, and the rest of the years above $3.5 \%$ (Figure 2). The average GDP per capita during the study period was USD 11,746 $\pm 3,570$ (range 3,974 - 16,792) and the average income per capita was USD 10,686 $\pm 3,146$ (range 3,698 - 15,037, Figure 2). Taiwan's economic growth was negatively correlated not only with GDP per capita (correlation coefficient $=-0.664, \mathrm{p}<0.001$, Table 1 ) but also with unemployment rate (correlation coefficient $=-0.611, \mathrm{p}<0.001$, Table $1)$. The average unemployment rate was $2.84 \% \pm 1.25(n=22)$ with maximum (5.17\%) in 2002 and minimum (1.45\%) in 1993. Taiwan's unemployment rate was positively correlated with the standardized suicide rates per 100,000 (correlation coefficient $=0.775, \mathrm{p}<0.001$, Table 1).

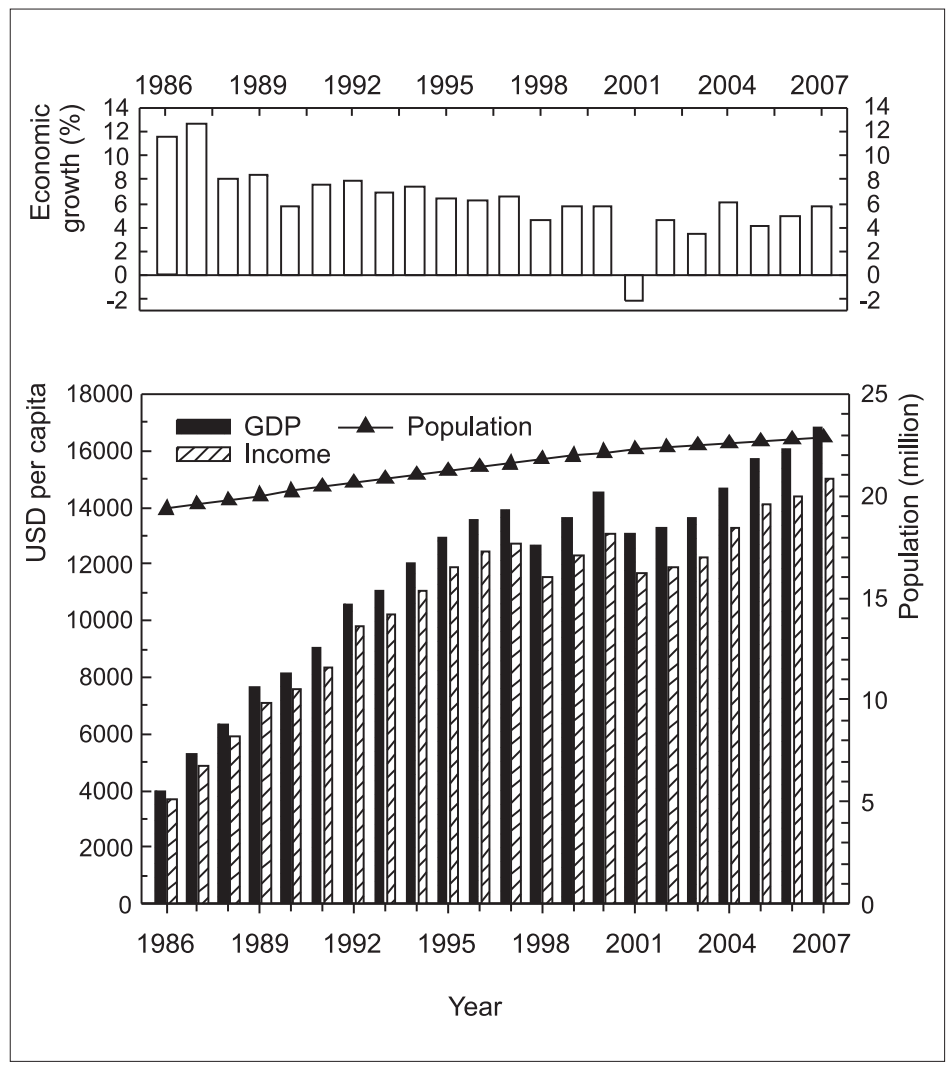

Economic growth GDP per capita Suicide rates Unemployment rate

$\begin{array}{llll}\text { Economic growth } & - & & \\ \text { GDP per capita } & -0.664^{* * *} & - & - \\ \text { Suicide rates } & -0.227 & 0.381 & - \\ \text { Unemployment rate } & -0.611^{* *} & 0.603^{* *} & 0.775^{* * *}\end{array}$

${ }^{*} \mathrm{p}<0.05 ;{ }^{* *} \mathrm{p}<0.01 ;{ }^{* *} \mathrm{p}<0.001$ 
DRUŠ. ISTRAŽ. ZAGREB GOD. 20 (2011)

BR. 1 (111)

STR. $137-150$

AGORAMOORTHY, G. HSU, M. J.:

SUICIDE IN TAIWAN'S.

$\frown$ FIGURE 3

Taiwan's unemploy ment rate (\%) and age-specific suicide rates (per 100,000) between 1986 and to 2007
More specifically, the unemployment rate was positively associated with the standardized age-specific suicide rates (per $100,000)$ from 20 to 65 years of age $(p<0.001$, Figure 3$)$, but not related to the younger age-group (below 20) and or older age-group (65 and above). The standardized suicide rates (per $100,000)$ were neither significantly correlated to Taiwan's economic growth, nor the GDP per capita ( $p>0.05)$ between 1986 and 2007 (Table 1).

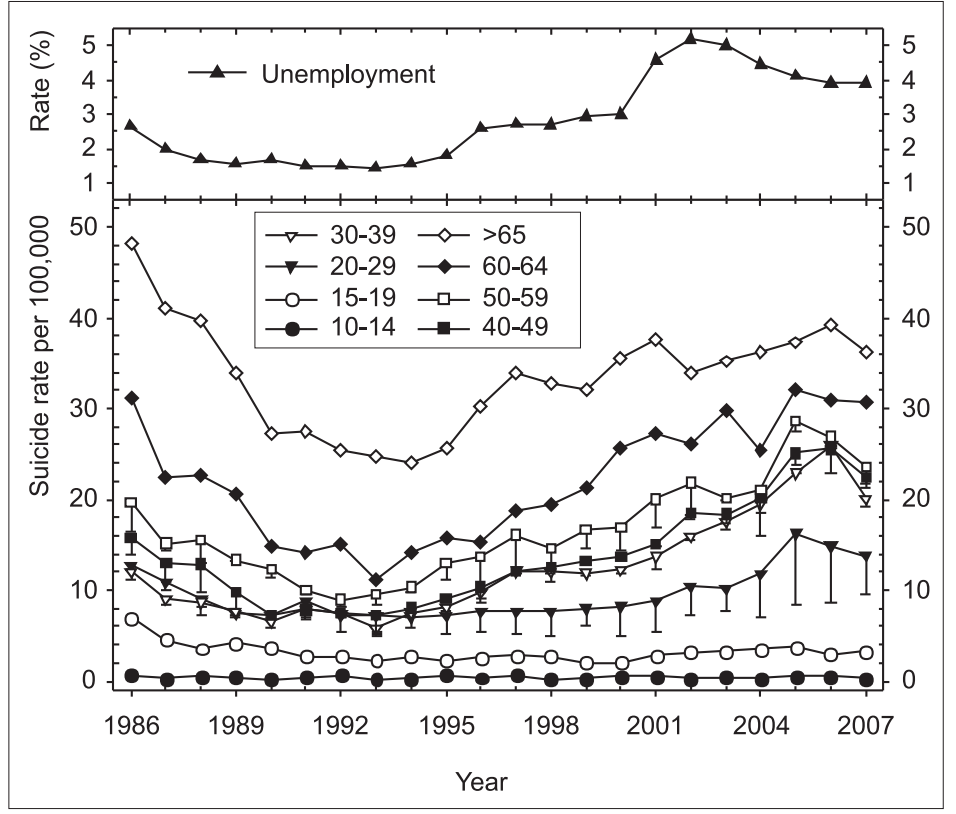

Our study also found significant differences between gender in unemployment rates (paired t-test, $\mathrm{t}=10.56, \mathrm{p}<0.001$ ) and in standardized suicide rates (paired t-test, $\mathrm{t}=3.63, \mathrm{p}<0.01$ ). Taiwan's average standardized suicide rate (per 100,000) for males was $13.9 \pm 4.4(n=22)$ nearly 1.89 times of that of females $(7.36 \pm 1.82)$. The average male unemployment rate was $3.01 \pm 1.46(n=22)$ nearly 1.16 times of that of the female $(2.58 \pm 0.98)$. Taiwan's standardized suicide rate was positively correlated with the unemployment rate in males (Pearson correlation coefficient $0.78, \mathrm{p}<0.001, \mathrm{n}=22$ ) as well as in females (Pearson correlation coefficient $=0.68, \mathrm{p}<0.01, \mathrm{n}=22$ ). However, the unemployment rate explained $61.5 \%$ of the variance of male suicide rates $\left(\mathrm{F}_{1,20}=31.98, \mathrm{p}<0.001\right)$ as compared to $46.9 \%$ in females $\left(\mathrm{F}_{1,20}=17.64, \mathrm{p}<0.01\right)$. When the unemployment rate $(X)$ increased to $1 \%$, the standardized male suicide rate (Y1) was predictably increased to $2.38 \%(\mathrm{Y} 1=6.779+$ $\left.2.377^{*} \mathrm{X}\right)$, which was nearly twice that of the female suicide rate $(Y 2, Y 2=4.079+1.272 * X)$. The two major causes of unemployment were unfulfilled jobs and first-time job seeking 
DRUŠ. ISTRAŽ. ZAGREB GOD. 20 (2011), BR. 1 (111)

STR. $137-150$

AGORAMOORTHY, G., HSU, M. J.:

SUICIDE IN TAIWAN'S

$\rightarrow$ FIGURE 4

Causes of

unemployment rate between 1986 and 2007 in Taiwan that accounted for nearly 62 to $73 \%$ of suicide causes before 1995 (Figure 4). However, from 1996 onwards, job losses and closure of companies became the second leading cause of unemployment, and this category topped the rank from 2001 to 2004 (35-46\%, Figure 4). The first-time job seeking became the third cause of unemployment from 1996 to 2007.

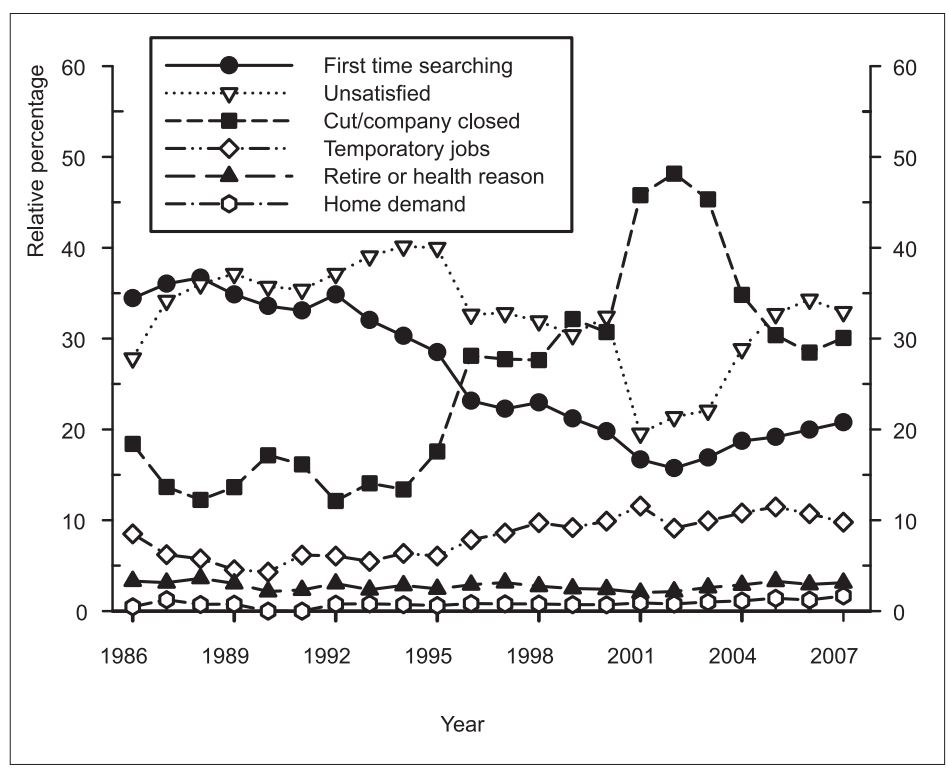

A total of 3,933 deaths contributed to suicide in Taiwan during 2007 with an average of 10.7 suicides per day or one suicide every two hours (standardized suicide rate 14.7 suicides $/ 100,000$ people). Besides, suicide became the third leading cause of death among Taiwan's teenagers with 238 teens committing suicide in 2007 alone. In Taipei City for example, the number of suicides between the age group of 15 and 24 increased from 21 in 2006 to 25 in 2007. Poor academic performance, study pressure and peer relationship problems were among the common causes triggering the young towards suicide. Similarly, an unusual increase in the suicide rate of young people has been reported from rural south India (Aaron et al., 2004).

Taiwan's mounting suicide problems are catalyzed often by job pressure, unemployment, recession, and a lack of socio-economic support systems in the society. Our analysis supports this notion that successful suicides committed by people in Taiwan between the ages of 20 and 65 were positively correlated with the standardized age-specific suicide rates related to unemployment and job losses (per 100,000). Similarly, when South Korea faced a serious financial crisis resulting in numerous job losses and unemployment in 1997, a chilling $35 \%$ surge in suicide was reported, and suicide be- 
DRUŠ. ISTRAŽ. ZAGREB GOD. 20 (2011),

BR. 1 (111)

STR. $137-150$

AGORAMOORTHY, G. HSU, M. J.:

SUICIDE IN TAIWAN'S. came South Korea's top killer for the first time in its history replacing traffic accidents (Watts, 1998). Increasing joblessness and liquidation usually lower peoples' expectations towards their future financial security, leading in the end to higher suicide rates. This could explain why suicide rates are comparatively higher during periods of economic crises. It further supports the economic theory of suicide, which predicts that when the future expected income goes beyond sustainability, people will have higher chances to commit suicide (Hamermesh and Soss, 1974).

\section{SUICIDE PREVENTION MEASURES AND CONCLUSIONS}

Taiwan's industrialized society rarely lets people bounce back from the perceived distress of socio-economic failure. Therefore the government of Taiwan must recognize suicide as a serious social health problem rather than an individual problem, and proactive measures must be put in place to prevent future incidents of suicide. Also, when it comes to reporting suicide, Taiwan's news media must realize their professional ethics and should refrain from glamorizing the suicide as a ritual phenomenon. Besides, the government of Taiwan must monitor internet sites and chat rooms that advertise suicide options with news bulletins and take immediate legal actions to punish the owners of such anti-social sites.

Taiwan can prevent suicide if timely attention is given to understanding the warning signs of depression. Young people must be carefully monitored and opportunities should be provided to relieve study and job-related pressures. Parents and family members must teach children the value of life and the meaning of death, especially if they show any signs of suicide. It is essential to set up more suicide prevention and intervention programs in schools, colleges and universities, as well as offices of corporations and governmental organizations. Suicide prevention must be taken up by each and every community member in the society to decelerate suicide rate in Taiwan. Also, urgent measure should be taken to restrict the use of charcoal and the user-friendliness of charcoal burning.

Government and non-government agencies involved in social work must play a leading role in the identification of high-risk groups, and then only effective financial and psychological interventions including counseling can be provided timely to reduce suicide across Taiwan. When people lose jobs or businesses abruptly, due to major government policy change, some opt for suicide. For example, when Taiwan allowed local firms to move operations overseas, many local people lost their jobs (BBC News, 2002). Therefore, the corporate and government sectors involved in businesses must show corporate social responsibility by providing timely financial assis- 
DRUŠ. ISTRAŽ. ZAGREB GOD. 20 (2011), BR. $1(111)$

STR. $137-150$

AGORAMOORTHY, G., HSU, M. J.:
SUICIDE IN TAIWAN'S.

tance to those who lose jobs and revenues, so that the affected could recover from the unexpected financial losses.

Taiwan has one of the highest levels of life expectancy in Asia, and it has eradicated infectious diseases such as the bubonic plague in 1948, smallpox in 1955, rabies in 1959, malaria in 1965, and polio in 2000 (Agoramoorthy and Hsu, 2006). Taiwan became the first country in the world to implement the Hepatitis B immunization program. Taiwan also initiated active vaccination against Japanese encephalitis in 1969, measles in 1978, hepatitis B in 1984, rubella in 1986, hepatitis A in 1995, and influenza in 1998. It is therefore time for Taiwan to take some serious steps to tackle the social health problem of suicide. We hope that Taiwan's experience and valuable lessons learnt from the health sector may contribute to the reduction of suicide in the near future.

\section{NOTES}

1 Suicide victims in Japan are known to make hydrogen-sulphide gas by mixing toilet cleaner with bath salts and this method claimed 60 lives in April 2008 alone - mostly young in their early 20s (McCurry, 2008). The colorless and pungent gas does not dissipate easily thus risking the lives of bystanders and rescuers as well. Similarly, car exhaust gas suicides went up to $10 \%$ of all suicide cases reported in Denmark (Thomsen and Gregersen, 2006).

2 More than a century ago, British naturalist Alfred Russel Wallace was impressed by the beauty of Taiwan and he wrote, 'Among recent continental islands there is probably none that surpasses in interest and instructiveness the Chinese island named by the Portuguese 'Formosa' (Wallace, 1880).

${ }^{3}$ Influence of religion on suicide has long been debated, especially whether Protestants or Roman Catholics have a higher suicide rate. This has preoccupied sociologists from the time when Durkheim (1897) published the classical piece on suicide (Pescosolido and Georgiana, 1989).

4 The relationship of Islamic religion with suicide has been widely discussed. A review of literature by Lester (2006) has examined the suicide rates in nations with predominant Muslim population and the analysis included both simple association and multivariate analyses.

5 The ethics of suicide in Buddhism, especially regarding the case of Channa has been discussed by Keown (1996).

\section{REFERENCES}

Aaron, R., Joseph, A., Abraham, S., Muliyil, J., George, K., Prasad, J., Minz, S., Abraham, V. J. and Bose, A. (2004), Suicides in Young People in Rural Southern India. The Lancet, 363: 1117-1118.

Agoramoorthy, G. and Hsu, M. J. (2006), Taiwan's Potential to Assist Developing Countries to Combat Infectious Diseases. PLoS Medicine, 3: 1192-1193. 
DRUŠ. ISTRAŽ. ZAGREB GOD. 20 (2011), BR. 1 (111)

STR. $137-150$

AGORAMOORTHY, G., HSU, M. J.:

SUICIDE IN TAIWAN'S.
Agoramoorthy, G. and Hsu, M. J. (2007a), Big Dream, Small Island - The Prospect of Taiwan's Biotech Economy. Drug Discovery Today, 12: 894-897.

Agoramoorthy, G. and Hsu, M. J. (2007b), Is Taiwan's Political and Economic Development an Environmental Nightmare? Environmental Politics, 16: 506-514.

BBC News (2002), China Woos Giant Taiwan Chip Firm. BBE News, http:// news.bbc.co.uk/2/hi/business/2223035.stm (accessed 8 November 2008).

Bertolotei, J. M. and Fleischmann, A. (2002), Suicide and Psychiatric Diagnosis: A Worldwide Perspective. World Psychiatry, 1: 181-185.

Durkheim, E. (1897), Le Suicide, Paris: Felix Alcan.

Eskin, M. (2004), The Effects of Religious Versus Secular Education on Suicide Ideation and Suicidal Attitudes in Adolescents in Turkey. Social Psychiatry and Psychiatric Epidemiology, 39: 536-542.

Farberow, N. L. (1975), Cultural History of Suicide. In: N. L. Farberow (Ed.), Suicide in Different Cultures (pp. 1-15). Baltimore, MD: University Park Press.

Gold, T. (1986), State and Society in the Taiwan Miracle, New York: M. E. Sharpe.

Hamermesh, D. S. and Soss, N. M. (1974), An Economic Theory of Suicide. Journal of Political Economy, 82: 83-98.

Hinton, L., Guo, Z., Hillygus, J. and Levkoff, S. (2000), Working with Culture: A Qualitative Analysis of Barriers to the Recruitment of Chinese-American Family Caregivers for Dementia Research. Journal of Cross-Cultural Gerontology, 15: 119-137.

Keown, D. (1996), Buddhism and Suicide: The Case of Channa. Journal of Buddhist Ethics, 3: 83-91.

Koshiro, T. (1988), Shi no oboegaki (Memoranda on Death). Bukkyo shiso, 10: 465-475.

Krastev, N. (2006), UN Body Takes on Rising Suicide Rates. http://www. rferl.org/content/article/1071203.html (accessed 8 November 2008).

Lee, R., Rodin, G., Devins, G. and Weiss, M. G. (2001), Illness Experience, Meaning and Help-Seeking among Chinese Immigrants in Canada with Chronic Fatigue and Weakness. Anthropology and Medicine, 8: 89-108.

Lester, D. (2006), Suicide and Islam. Archives of Suicide Research, 10: 77-97. Lester, D. (2008), Suicide and Culture. World Cultural Psychiatry Research Review, 3: 51-68.

Lin, K. M., Inui, T. S., Kleinman, A. M. and Womack, W. M. (1982), Sociocultural Determinants of the Help-Seeking Behavior of Patients with Mental Illness. Journal of Nervous and Mental Disease, 170: 78-85. Lo, P. C. (1999), Confusian Ethics Death with Dignity and its Contemporary Relevance. Annual of the Society of Christian Ethics, 19: 313-333. McCurry, J. (2008), Police Warn against Suicide Gas that Can Kill Neighbors, Guardian, 1 May, http://www.buzzle.com/articles/192987.html (accessed 8 November 2008).

Nystedt, D. (2006), Taiwan Investment to China up 46\% in 2006, Info World, 21 June, http://www.infoworld.com/t/business/taiwan-investmentchina-46-in-2006-060 (accessed 8 November 2008). 
DRUŠ. ISTRAŽ. ZAGREB GOD. 20 (2011), BR. 1 (111)

STR. $137-150$

AGORAMOORTHY, G., HSU, M. J.:

SUICIDE IN TAIWAN'S...
Pescosolido, B. A. and Georgiana, S. (1989), Durkheim, Suicide and Religion. American Sociological Review, 54: 33-48.

Sutter, R. (2006), The Taiwan Problem in the Second George W. Bush Administration: US Officials' Views and their Implications for US Policy. Journal of Contemporary China, 15: 417-441.

Taiwan National Statistics (2006), http://eng.stat.gov.tw (accessed 8 November 2008).

Thomsen, A. H. and Gregersen, M. (2006), Suicide by Carbon Monoxide from Car Exhaust-Gas in Denmark 1995-1999. Forensic Science International, 161: 41-46.

Tzeng, W. C. (2001), Being Trapped in a Circle: Life after a Suicide Attempt in Taiwan. Journal of Transcultural Nursing, 12: 302-309.

Vijayakumar, L. (2005), Suicide and Mental Disorders in Asia. International Review of Psychiatry, 17: 109-114.

Vuokila-Oikkonen, P., Janhonen, S. and Nikkonen, M. (2002), Patient Initiatives in Psychiatric Care Concerning Shamein the Discussion in Co-Operative Team Meetings. Journal of Psychiatric and Mental Health Nursing, 9: 23-32.

Wallace, A. R. (1880), Island Life, London: MacMillan and Co.

Watts, J. (1998), Suicide Rate Rises as South Korea's Economy Falters. The Lancet, 352: 1365.

White, L. (2005), Taiwan's Success and Its Challenges for the Future. South African Journal of International Affairs, 12: 157-166.

Xu, J. M. (1987), Some Issues in the Diagnosis of Depression in China. Canadian Journal of Psychiatry, 32: 368-370.

Zhang, J. and Jin, S. (1996), Determinants of Suicide Ideation: A Comparison of Chinese and American College Students. Adolescence, 31: 451-467.

Zheng, Y. P., Xu, L. Y. and Shen, Q. J. (1986), Styles of Verbal Expression of Emotional and Physical Experiences: A Study of Depressed Patients and Normal Controls in China. Culture, Medicine and Psychiatry, 10: 231-243.

\section{Suicid u tajvanskom društvu}

Govindasamy AGORAMOORTHY

Fakultet društvenih znanosti, Sveučilište Tajen, Pingtung, Taiwan

Minna J. HSU

Odsjek za biološke znanosti,

Nacionalno sveučilište Sun Yat-sen, Kaohsiung, Taiwan

Tajvan je suvremeni industrijalizirani megalopolis koji se nalazi na samom rubu drevne kineske kulture. Ovaj je maleni otok $u$ zadnjih nekoliko desetljeća prešao put od nerazvijene poljoprivredne zabiti do svjetski važnoga tehnološkog diva. Ali usprkos gospodarskom blagostanju i demokratskim reformama, pojavili su se dodatni društveni problemi, 
DRUŠ. ISTRAŽ. ZAGREB GOD. 20 (2011)

BR. $1(111)$

STR. 137-150

AGORAMOORTHY, G. HSU, M. J.:

SUICIDE IN TAIWAN'S. uključujući suicid, koji je od 1982. godine do danas postao jednim od deset glavnih uzroka smrti. U ovom se radu podastiru podaci o broju samoubojstava na Tajvanu od 1986. do 2007. godine. Razmatraju se društveno-kulturni, vjerski i gospodarski čimbenici povezani sa samoubojstvom u tajvanskom društvu. Iznose se i neke miere za smanjivanje broja suicida na Tajvanu u bliskoj budućnosti.

Kliučne riječi: uzroci suicida, metode izvršavanja suicida, viera, društvo, Tajvan

\section{Selbstmordrate in der taiwanesischen Gesellschaft}

Govindasamy AGORAMOORTHY

Gesellschaftswissenschaftliche Fakultät, Universität Tajen,

Pingtung, Taiwan

Minna J. HSU

Abteilung für Biowissenschaften, Volksuniversität Sun Yat-sen, Kaohsiung, Taiwan

Taiwan ist ein modernes, industrialisiertes Megalopolis im Randgebiet des traditionellen chinesischen Kulturkreises. Die kleinflächige Insel hat sich in nur wenigen Jahrzehnten aus einer unterentwickelten ländlichen Provinz zu einem international relevanten technologischen Riesen entwickelt. Trotz des wirtschaftlichen Aufschwungs, trotz Wohlstand und demokratischen Reformen treten jedoch schwerwiegende gesellschaffliche Probleme auf, darunter auch das Suizid, das von 1982 bis heute zu den zehn Haupttodesursachen in Taiwan gehört. Die Verfasser präsentieren in ihrem Artikel die Selbstmordraten in Taiwan von 1986 bis 2007 und untersuchen bestimmte gesellschaftlich-kulturelle, religiöse und wirtschaftliche Faktoren, die bei diesem Phänomen zum Tragen kommen. Des Weiteren werden Maßnahmen erörtert, die möglichst bald schon zum Rückgang der Selbstmordfälle beitragen sollen.

Schlüsselbegriffe: Selbstmordursachen, Methoden der Selbsttötung, Religion, Gesellschaft, Taiwan 